\title{
O wagnerismo de Alberto Nepomuceno e sua evolução na canção de câmara ${ }^{1}$
}

\author{
Alberto Nepomuceno's Wagnerism and its Evolution in the Art Song
}

João Vicente Vidal

Universidade Federal do Rio de Janeiro

\begin{abstract}
Resumo: Na historiografia musical brasileira, grande destaque foi dado ao papel de Alberto Nepomuceno no processo de formação de uma canção de câmara "brasileira", cantada em português e de caráter nacionalista. Pouca atenção se deu, porém, ao papel do wagnerismo do compositor neste mesmo processo. Articulando uma contextualização histórica do fenômeno à apreciação analítica de uma amostra da produção do compositor, o estudo procura evidenciar sua compreensão e emprego de "categorias" wagnerianas de composição musical entre os anos de 1894 e 1901. Em perspectiva histórica e comparativa, culminando com um exame mais detido da canção vernacular Turqueza op. 26 n. 1, torna-se possível delinear aspectos gerais e específicos do wagnerismo de Nepomuceno, englobando três diferentes "soluções" do compositor para o problema do Lied wagnerista de sua época.
\end{abstract}

Palavras-chave: Nepomuceno; wagnerismo; canção de câmara

\begin{abstract}
In Brazilian musical historiography, great emphasis was given to the role of Alberto Nepomuceno in the formation process of a "Brazilian" Art Song, sung in Portuguese and of a nationalist character. Little attention was given, however, to the role of his Wagnerism in this same process. Articulating a historical contextualization of the phenomenon with an analytical appreciation of a sample of the composer's oeuvre, the study seeks to reveal his understanding and use of Wagnerian "categories" of musical composition between the years 1894 and 1901. In a historical and comparative perspective, culminating in a closer examination of the vernacular song Turqueza op. 26 No. 1, it becomes possible to
\end{abstract}

\footnotetext{
${ }^{1}$ Muito das reflexões contidas neste trabalho é devido ao trabalho com alunos da Escola de Música não apenas no âmbito de seu Programa de Pós-Graduação em Música, mas também, e até certo ponto fundamentalmente, à experiência prática com a canção de câmara de Alberto Nepomuceno com alunos de canto e piano dos cursos de Graduação, no âmbito da disciplina "Transposição e acompanhamento ao piano". Pela inestimável oportunidade de aliar a investigação histórica à prática interpretativa, portanto, agradecimentos são devidos aos nossos alunos, aos monitores da disciplina e à nossa colega de cátedra, Profa. Lúcia Elizabeth Dittert.
} 
outline general and specific aspects of Nepomuceno's Wagnerism, encompassing three different "solutions" of the composer to the problem of the Wagnerist Lied of his time.

Keywords: Nepomuceno; Wagnerism; Art Song

\section{Introdução}

O wagnerismo ${ }^{2}$ de Alberto Nepomuceno (1864-1920) conta-se entre os tópicos da pesquisa sobre o compositor que, embora frequentemente evocados, carecem ainda de abordagens privilegiando perspectivas analíticas, capazes de evidenciar como princípios estéticos e técnicos típicos do compositor alemão efetivamente se revelam nas partituras de Nepomuceno. O desafio maior, neste caso, parece ser a dificuldade de se realizar um aprofundamento "sistemático" sem que seja oferecida também uma fundamentação histórica do fenômeno, capaz de situar (ainda que minimamente) o wagnerismo do compositor em perspectiva temporal e mesmo geográfica, e ainda a necessidade relacionada de trazer à luz o fenômeno através de uma amostra consistente da obra de ambos os compositores (e, no caso de Wagner, de seu hermético universo conceitual particular). O exame do wagnerismo de Nepomuceno conduz o pesquisador, portanto, a dificuldades relacionadas à coordenação (ou conciliação) de uma ampla gama de referenciais teóricos e metodologias: estética da recepção, intertextualidade, abordagens analíticas relacionadas a harmonia, trabalho temático-motívico, textura e ritmo.

Menos problemática, embora não menos complexa, revela-se em comparação a relação de Nepomuceno com Brahms e as tradições austrogermânicas pré-clássicas, no âmbito de sua música instrumental. Neste caso, como evidenciado em estudos abrangidos grosso modo na última década e meia, uma recepção "produtiva"3 da música de Brahms e seus precursores resultou em

\footnotetext{
${ }^{2}$ Utilizamos os adjetivos "wagneriano" e "wagnerista" para fazer referência respectivamente ao compositor (por exemplo "harmonia wagneriana" para "harmonia de Wagner") e a seus imitadores e epígonos ("procedimento wagnerista" para "procedimento à maneira de Wagner"). A distinção encontra respaldo já nas primeiras etapas da recepção do compositor, notadamente na França, onde cedo difundiram-se as expressões wagnérien (para coisa relativa ao compositor, como no título do periódico Revue Wagnérienne) e wagnérisme (para tudo relacionado ao movimento em torno de Wagner). Assim, também apenas uma forma substantivada da palavra é empregada ("wagnerismo").

${ }^{3}$ Com a expressão indicamos o que na literatura musicológica de língua alemã convencionou-se chamar "kompositorische Rezeption", ou seja a recepção tal como praticada por compositores,
} 
uma compreensão e incorporação bastante esclarecidas de técnicas como "variação progressiva" do material (Dudeque 2005), "dissonância métrica" e "deslocamento métrico" de uma ou mais camadas de uma textura (Vidal 2014, p. 270), entre outras, demonstrações de domínio dessas técnicas nem sempre vinculadas a citações diretas ou paráfrases de obras brahmsianas, mas em grande medida aplicadas também a contextos originais de concepção musical. A compreensão da relação de Nepomuceno com Wagner, porém, e isso vale também para outros compositores brasileiros da mesma época (Leopoldo Miguéz sendo sem dúvida o mais célebre), foi dificultada por vezes pelo caráter abrangente do fenômeno wagneriano no final do século XIX e início do XX - uma revolução musical e cultural, a um só tempo. Com frequência, a natureza eminentemente interdisciplinar do "problema" Wagner desviou o foco da discussão da música para o seu contexto exterior (que seria impactado também, ao longo do século XX, pelas conhecidas implicações sociais e políticas da questão, em certos casos perdurando até hoje).

No que segue, procuramos caracterizar e compreender o wagnerismo de Nepomuceno no âmbito de um gênero de enorme importância para o compositor, e ao qual parte de sua reputação póstuma é devida: a canção de câmara. Na literatura musicológica nacional, rica em avaliações da produção vocal camerística de Nepomuceno, grande ênfase foi tradicionalmente dada aos aspectos do conjunto em sintonia com os interesses particulares de uma pesquisa musical guiada por premissas do movimento modernista. E muito embora o paradigma tenha sido consistentemente explorado e revisto em tempos recentes, notadamente por Coelho de Souza (2010), que, refutando a hipótese de Nepomuceno como "fundador" da canção de câmara brasileira, relacionou sua produção às tradições do Lied alemão e da mélodie francesa (abrangidas nesta as "influências progressistas da mélodie franco-wagneriana"), a canção de câmara de Nepomuceno como um terreno fértil para interpretações de sua trajetória e eclética técnica composicional. Neste sentido, e buscando melhor compreender a evolução da recepção de Wagner por Nepomuceno a partir de uma breve seleção de obras compostas entre os anos de 1894 e 1901, procuramos explorar esta

envolvendo "novas criações consumadas [...] no confrontamento com a música de tempos anteriores [...] [nas quais] a divisão de produção e recepção é em grande medida suspensa" (Schäfer 1999, p. 7). 
seleção à luz de "categorias" wagnerianas de composição musical, ${ }^{4}$ para o que tomamos como principal referência a crítica de Carl Dahlhaus $(1971,1984)^{5}$ - que, escapando à apologia e à polêmica, procurou por compreender a obra de Wagner desde as suas próprias premissas técnicas e estéticas, realizando para tal uma elaborada amálgama de análise estrutural e história da recepção. Nesta apreciação do wagnerismo de Nepomuceno na canção de câmara, uma ênfase maior é dada à canção vernacular Turqueza op. 26 n. 1 (1901), cuja análise, porém, não poderia deixar de ser precedida tanto por uma breve contextualização da disposição do compositor em relação a Wagner, quanto por uma recapitulação de algumas das experiências wagneristas prévias de Nepomuceno. Como concluímos, ambos os elementos conferem à análise da questão uma imprescindível perspectiva histórica e comparativa, com base na qual busca-se delinear, na parte final do artigo, aspectos gerais e específicos do wagnerismo de Nepomuceno.

\section{Nepomuceno e Wagner: contexto de uma recepção composicional}

Naquela que pode ser considerada a primeira associação pública de Nepomuceno (como compositor) a Wagner, o jornal cearense Libertador reportava

\footnotetext{
${ }^{4}$ Tamanha foi a individualidade de Wagner que para a sua música sequer o vocabulário convencional serviu, razão pela qual criou ele mesmo uma massa terminológica própria, uma densa rede de conceitos como Gesamtkunstwerk ("obra de arte total"), Kunstwerk der Zukunft ("obra de arte do futuro"), Bühnenfestspiel ("peça de festival cênico"), Worttonsprache ("linguagem de som e palavra"), Versmelodie ("melodia de versos"), unendliche Melodie ("melodia infinita") etc. A estes somaram-se outros, à medida que progredia a recepção e pesquisa musical em torno de sua música, o mais conhecido dos quais sendo o termo Leitmotiv ("motivo condutor", uma ideia musical claramente definida, associada a um elemento qualquer da obra, e que retém sua identidade mesmo quando submetida às mais diversas variações), popularizado por Hans von Wolzogen a partir de 1876 (em Thematischer Leitfaden durch die Musik von R. Wagners Festspiel 'Der Ring des Nibelungen'). É notável que a obra de Wagner tenha continuado a inspirar a formulação de conceitos que a explicassem muitas décadas depois das datas de composição ou da morte do compositor. Por exemplo, e como veremos, pelo compositor e teórico Arnold Schönberg.

${ }^{5}$ A fim de colocar em perspectiva histórica não apenas o objeto em questão, como também o referencial teórico a partir do qual é este abordado, informamos neste ponto as datas das primeiras edições das obras de Dahlhaus consultadas; ao longo do texto, são referidas as datas das edições utilizadas (1996 e 1994, respectivamente). Do segundo livro, assinado por Dahlhaus e John Deathridge e derivado diretamente de um verbete do The New Grove Dictionary de 1980, utilizamos apenas o segundo capítulo de Dahlhaus (referido, portanto, como o único autor, a cada citação).
} 
MUSICA THEORICA Revista da Associação Brasileira de Teoria e Análise Musical 2020,

v. 5, n. 1, p. 321-349 - Journal of the Brazilian Society for Music

Theory and Analysis @ TeMA 2020 - ISSN 2525-5541

seu desempenho no recém-realizado concurso para escolha do Hino Nacional descrevendo Nepomuceno como "um modernista [qu]e adora a escola wagneriana, [que] espera concluir seus estudos em Leipzig ou Munich [sic]" (Libertador, 15 fev. 1890, p. 3). Poucos meses depois, a 30 de maio, Nepomuceno escreve a Frederico Nascimento, expondo no contexto de uma detalhada discussão sobre o tratado La polifonia nell'arte moderna spiegata secondo i principi classici de Cesare De Sanctis (muito provavelmente o único comentário remanescente de Nepomuceno sobre uma obra teórico-musical qualquer), suas próprias ideias acerca dos experimentos harmônicos de Mendelssohn e Wagner:

Tenho pensado em propor ao Instituto Nacional a adaptação do [...] tratado do De Sanctis intitulado 'La Polifonia' [...] A parte, então, relativa as alterações é muito completa e enriquecida de esplêndidos exemplos. Outro sim, a maioria dos exemplos são tirados das obras dos mestres, assim é que lá encontrarás trechos de Beethoven, Bach, Berlioz, Boito, Goldmark, Haydn, Händel, Liszt, Palestrina, Weber e Wagner. Esclarece muito a mente e dá um efeito obtido por tal ou qual agregação, ou alteração, ou pedal ou enarmonia. [...] Ele não deixa de ter os seus defeitos, como por exemplo tratando da alteração de certos intervalos de certos acordes de $7^{\mathrm{a}} \mathrm{e} 9^{\mathrm{a}}$ e das agregações de 6 sons diz serem impossíveis certas inversões que eu acho naturalíssimas. É a tal coisa de encontro de notas, da arte como eles dizem, mas sem lembrarem-se que os tratados repelem a $4^{a}$ inversão dos acordes de $9^{a} \mathrm{e}$ Wagner a fez na Marcha nupcial de Lohengrin com um resultado estupendo e Mendelssohn na Ouverture de Sommernachtstraum. São as tais coisas que quando são feitas os técnicos tratam de explicar ou por uma antecipação, ou retardo, ou appoggiatura etc.... sendo que o mais das vezes só com muita força de boa vontade se aceita a explicação (Nepomuceno 1890).

Nepomuceno encontrava-se então na Itália, para onde transferiu-se em 1888 com o auxílio dos irmãos Henrique e Rodolfo Bernardelli. Estudando composição no Liceo Musicale Santa Cecilia em Roma com Eugenio Terziani e De Sanctis, Nepomuceno possuía então uma razoável trajetória artística e uma personalidade intelectual forjada no contato com o movimento abolicionista, com o republicanismo e, mais decisivamente, com o germanismo da Escola do Recife ${ }^{6}$

\footnotetext{
${ }^{6}$ Dito resumidamente, os "germanistas" da Escola do Recife, Tobias Barreto e Silvio Romero por exemplo, almejavam um deslocamento do eixo cultural brasileiro da França para a Alemanha, que seria uma melhor "pátria intelectual". A noção de que a formação humanística de Nepomuceno em seus primeiros anos teria pesado decisivamente na escolha do seu campo de atuação profissional (música da tradição austro-germânica, e não ópera italiana), bem como a expressão "formação germânica" para descrever a construção de sua personalidade intelectual e artística nesse período, foram sugeridas por nós em outra ocasião (Vidal 2014).
} 
(Vidal 2014 e 2015). Muito coerentemente, Nepomuceno conectou-se em Roma a uma escola de compositores italianos cuja ambição era empreender uma "restauração" da música instrumental italiana, percebida como estagnada ao longo do século XIX. Promovendo a música austro-germânica e emulando suas formas de música de câmara e sinfônica, tinham por objetivo uma atualização técnica e estética da música instrumental do país. Como comentou Massimo Mila, contudo, o movimento tinha seu significado histórico marcado pelo anacronismo inerente aos próprios ideais:

Seus modelos, eles diziam, eram Brahms, Wagner e Liszt, mas na realidade Beethoven, Mendelssohn e Schumann, e isso em uma época em que Mahler, Strauss e Debussy estavam prestes a tornar-se os principais mestres. Os pioneiros da ressurreição instrumental estavam necessariamente uma geração atrasados (Mila 1957, p. 1543-1544).

Da análise da formação de Nepomuceno nos anos subsequentes, de 1890 a 1895 (Vidal 2014), obtemos informações sobre como o interesse de Nepomuceno por Wagner seria por um lado dificultado pelo conservadorismo das instituições que frequentou na Alemanha, mas por outro lado estimulado no contato com a entusiástica recepção do compositor alemão na França. De seus professores em Berlim, Heinrich von Herzogenberg e Max Bruch colocavam-se decididamente entre opositores do "progressismo" musical de Wagner e da Neudeutsche Schule ("Nova Escola Alemã", termo cunhado pelo crítico Franz Brendel para definir a música de Liszt, Berlioz e Wagner) - uma atitude que, por encontrar-se "enraizada na tradição da Akademie der Künste de Berlim", recebeu o nome de "academicismo" (Karl Fellerer apud Vidal 2014, p. 75); Arno Kleffel, seu professor no Stern'sches Konservatorium der Musik, embora de opinião menos negativa em relação a Wagner, não podia evitar o fato de que "o antiwagnerianismo tinha se refugiado nos conservatórios [da Alemanha] como em uma fortaleza" (Bruno Walter apud Vidal 2014, p. 313). Na Schola Cantorum de Paris, porém, onde completaria um último ano completo em sua jornada de estudos na Europa, Nepomuceno tomou contato com a recepção entusiástica de Wagner na França, que permeava os mais diferentes aspectos do ambiente cultural francês da época.

Como este breve resumo da formação de Nepomuceno na Europa deixa claro, o "problema Wagner" tornara-se já-pelo menos desde o sucesso de Die Meistersinger von Nürnberg em 1868, e de Der Ring des Nibelungen na década 
seguinte, quando Wagner tornou-se inquestionavelmente a figura dominante da música alemã-uma questão inescapável para qualquer jovem compositor. Ainda assim, é difícil de precisar como Nepomuceno teria se familiarizado com e aprofundado sua compreensão das categorias musicais wagnerianas. No âmbito das instituições frequentadas, e até onde a apreciação da música de Wagner era admitida, constata-se uma compreensão relativamente limitada das inovações técnicas de Wagner. Por exemplo, tanto De Sanctis em La polifonia nell'arte moderna spiegata secondo i principi classici, quanto Vincent D'Indy no Cours de composition musicale, ${ }^{7}$ ao tratar de Wagner quando o tema é a expansão da tonalidade clássica, ou seja a harmonia cromática, compreendem os experimentos do compositor alemão (como por exemplo o célebre "acorde de Tristão") não como rupturas com a prática comum clássico-romântica, mas antes como resultado de elaborações de estruturas diatônicas (Vidal 2014, p. 375).

Como sugerimos em outra ocasião, "pode-se assim concluir que uma compreensão de tais conceitos [wagnerianos] foi adquirida através do contato direto com as partituras e, num plano teórico, com os escritos de e sobre Wagner circulantes em toda a Europa e especialmente em Paris" (2014, p. 376-377), suposição corroborada pela constatação de que "maioria dos títulos de e sobre Wagner pertencentes à biblioteca do Instituto Nacional de Música na virada do século XIX para o XX era francesa e não alemã" (p. 374). Não se deve, neste ponto, deixar de considerar o papel que possa ter desempenhado aí aquilo que Rémy Campos e Nicolas Donin definiram como "a emergência de novas práticas cultas de leitura e de escuta na França no final do século XIX" , no seio das quais a prática analítica despontava como importante veículo para uma "aculturação francesa da estética wagneriana" (2009, p. 35). No que segue, buscaremos rastrear a compreensão e aplicação de conceitos wagnerianos por Nepomuceno em três exemplos de sua canção de câmara: Einklang e Sehnsucht nach Vergessen, do ciclo Fünf Gedichte von Nicolaus Lenau für eine Singstimme (1894), e Turqueza op. 26 n. 1 (1901). Uma breve menção ao prólogo de Artémis (1898), ilustrando aspectos complementares da recepção de Wagner por Nepomuceno, é interpolada entra as duas primeiras canções e a última.

\footnotetext{
${ }^{7}$ Segundo D'Indy "redigido [...] de acordo com as notas tomadas nas classes de composição da Schola Cantorum em 1897-1898", e assim relacionável ao aprendizado teórico que Nepomuceno possa ter recebido ali anos antes.
} 


\section{O Lied wagnerista como "problema" técnico-estético: Einklang e Sehnsucht nach Vergessen}

O que se propõe analisar, como visto, é um problema aparentemente surgido na esteira do avanço do wagnerismo na Europa no último quarto do século XIX: como transpor as "categorias" wagnerianas para a canção de câmara. Comparativamente, revelava-se menos problemática a absorção destas pelo meio sinfônico ou mesmo de câmara. Como comentou Carolyn Abbate comentou, "por volta do final do século XIX, as modulações 'inaceitáveis' de Wagner [...] tinham se tornado a mais comum das moedas. Todas as interrupções não-reparadas, conflitos tonais não-resolvidos, justaposições não-mediadas-enfim, todos os artifícios que Wagner elaborara como transgressões das regras da música absoluta e como projeções da poesia-foram absorvidos na música sinfônica" (Abbate 1989, p. 56). Um exemplo precoce da integração de elementos wagnerianos à técnica composicional de Nepomuceno, no âmbito da música de câmara e revelando uma compreensão do estilo mais voltada à intensificação do cromatismo, em passagens marcadas por maior independência das partes, é a primeira versão do primeiro movimento do Quarteto de cordas n. 3 em Ré menor, recentemente publicada (Vidal 2020), e relacionado diretamente a seus estudos com Herzogenberg e Bruch na Akademie der Künste de Berlim.

O desafio da canção de câmara, porém, era inteiramente de outra ordem. Criar um Lied wagnerista significava, de fato, introduzir em um gênero de longa tradição, e tendo como ideal uma relação íntima (e até certo ponto codificada) entre poema e música, elementos estilísticos inteiramente contraditórios. Dito de outro modo, o problema era como tornar dramático um gênero lírico por excelência, com a tonalidade diatônica como premissa teórica inquestionável e uma tendência à periodicidade melódica que não raro o aproximava do popular e folclórico. Neste ponto, a (breve) obra para canto e piano do próprio Wagner não oferecia um modelo satisfatório: nos Fünf Gedichte für eine Frauenstimme sobre poemas de Mathilde Wesendonck (dois dos quais foram descritos pelo compositor como "estudos para Tristan und Isolde") predomina o caráter de redução para piano de uma textura orquestral. Também Hugo Wolf, um wagnerista obcecado, não pode ser considerado senão como um modelo afastado para Nepomuceno (Coelho de Souza 2010, p. 36). É portanto notável o que Nepomuceno logra realizar em seu ciclo de canções em alemão Fünf Gedichte von 
MUSICA THEORICA Revista da Associação Brasileira de Teoria e Análise Musical 2020,

v. 5, n. 1, p. 321-349 - Journal of the Brazilian Society for Music

Theory and Analysis @ TeMA 2020 - ISSN 2525-5541

Nicolaus Lenau für eine Singstimme, composto em Paris em 1894 e concebido não como estudos para projetos operísticos, mas antes como reivindicações sérias no campo da canção de câmara (vale notar que sobre poemas de Lenau foram compostos numerosos Lieder na segunda metade do século XIX, mais frequentemente por Schumann e Hugo Wolf, mas também por Mendelssohn, Liszt e Richard Strauss).

Na primeira peça do ciclo, Einklang (“Uníssono"), vemos um conjunto de características que permitem descrever a obra como a primeira "solução" concebida por Nepomuceno para o problema do Lied wagnerista. Sem repetir em detalhe a análise proposta em outra ocasião (Vidal 2014), esta consistia da elaboração minimalista, durchkomponiert, de uma linguagem altamente cromática (e de fato quase atonal), que faz da canção o mais avançado experimento musical do compositor até a data, radicalmente afastado de qualquer modelo que o Lied alemão do século XIX pudesse oferecer. Excetuando-se o episódio inicial de Wortmalerei ("pintura de palavras", recurso típico do Lied) em que o piano simula as doze badaladas à meia-noite referidas no poema de Lenau, todo o resto remete diretamente a Wagner: com sua "uma qualidade híbrida de canto e recitativo" (Vidal 2014, p. 380), remetendo ao Sprechgesang ("canto falado"), wagneriano, a linha do soprano revela o "esquematismo da divisão rítmica" que surge em Wagner "como reverso e reação de uma emancipação da melodia" (Dahlhaus 1996, p. 33) (Ex. 1); a constituição do tipo de ambiente harmônico que seria descrito por Arnold Schönberg como schwebende Tonalität ("tonalidade flutuante"), em substituição à tonalidade centrípeta clássica, incluindo o emprego de vagierende Akkorde ("acordes errantes"), ${ }^{8}$ facilmente cambiáveis por enarmonia (ver também Coelho de Souza 2006, p. 78); a relação de interdependência dos dois primeiros elementos (melodia e harmonia), cuja

\footnotetext{
${ }^{8}$ Schönberg explicava em 1911 sua noção de schwebende Tonalität ("tonalidade flutuante") tomando por ilustração precisamente o prelúdio de Tristan, de 1859: "percebe-se que a tonalidade de lá menor, embora possa ser inferida de cada passagem, praticamente nunca é verdadeiramente tocada em toda a peça. Ela é sempre expressa de forma circundante, sempre é evitada por meio de uma cadência deceptiva" (Schönberg 1922, p. 460). Embora Schönberg não tenha formulado uma diferenciação inequívoca entre este conceito e aquela de aufgehobene Tonalität ("tonalidade suspensa") pode-se apreender de seus escritos que esta segunda se reservaria mais para passagens de caráter mais modulatório: "uma semelhança não de todo distante com esta têm as seções de desenvolvimento clássicas, em que os momentos individuais, embora expressando incondicionalmente uma tonalidade, o fazem de modo tão pouco sustentado que pode-se perdêla num piscar de olhos" (p. 460).
} 
interação corresponde à descrição de Dahlhaus, para quem "a melodia", em Tristan und Isolde é "dependente da estrutura dos acordes e vice-versa. [...] A harmonia é amparada e motivada pela melodia, assim como a melodia adquire significado e colorido através da harmonia" (1996, p. 93-94); e, finalmente, corroborando a referência central do ponto anterior, uma citação completa do “acorde de Tristão" (c. 17-19), incluindo a resolução tal como no prelúdio de Tristan und Isolde (Ex. 1).
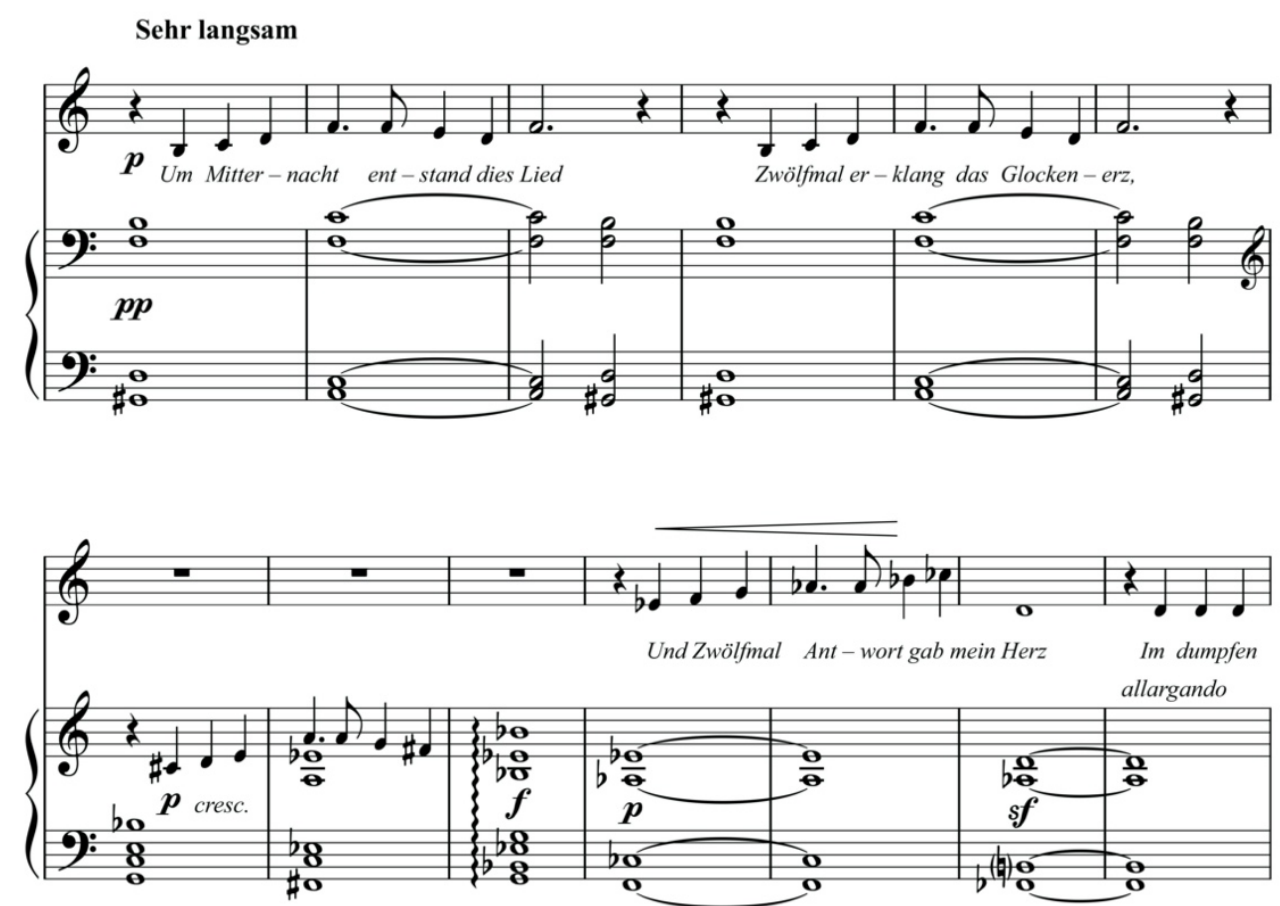

Exemplo 1: Nepomuceno, Einklang, c. 8-19 (“acorde de Tristão" no c. 17; ver Ex. 5)

$\mathrm{Na}$ última peça do ciclo, Sehnsucht nach Vergessen ("Ânsia pelo esquecimento"), observamos o que pode ser descrito como uma segunda "solução" de Nepomuceno para o problema da transposição da linguagem wagneriana para o gênero da canção de câmara. Se em Einklang Nepomuceno concentrou seus esforços nos parâmetros de melodia e harmonia, que manipula, como Wagner em Tristan, de modo a promover a "emancipação da melodia e do contraponto de um nexo cordal pré-configurado" (Dahlhaus 1996, p. 95), em Sehnsucht nach Vergessen vemos o compositor focado muito mais nos parâmetros de textura e frase. A textura do acompanhamento, aqui, adquire o já mencionado aspecto de redução para piano de uma partitura orquestral, dominado por tremolandi, com um uso abrangente dos recursos do instrumento (Ex. 2), 
MUSICA THEORICA Revista da Associação Brasileira de Teoria e Análise Musical 2020, v. 5, n. 1, p. 321-349 - Journal of the Brazilian Society for Music

coerentemente com o caráter operístico da parte vocal. Do ponto de vista harmônico, observa-se em Sehnsucht nach Vergessen a característica essencial da harmonia "progressiva" do século XIX (representada paradigmaticamente por Tristan, mais do que qualquer outra obra): a "complicação da técnica da dissonância" associada à "tendência à cromatização dos acordes, ao 'matizar' notas individuais através de elevação ou abaixamento" (Dahlhaus 1996, p. 106). Predominam na canção acordes de quatro sons de todos os tipos, tríades aumentadas, diminutas etc., e embora possa-se falar ainda de uma tonalidade "centrípeta", isto é, girando em torno de uma tônica (Fá menor, no caso), podese perceber em seu encadeamento o germe do que Nicholas Cook definiu como o "constante senso de modulação em direção a objetivos que estão sempre mudando antes de ser atingidos" (Cook 1987, p. 64), geralmente considerado como a condição de realização, no plano harmônico, da unendliche Melodie ("melodia infinita") wagneriana.
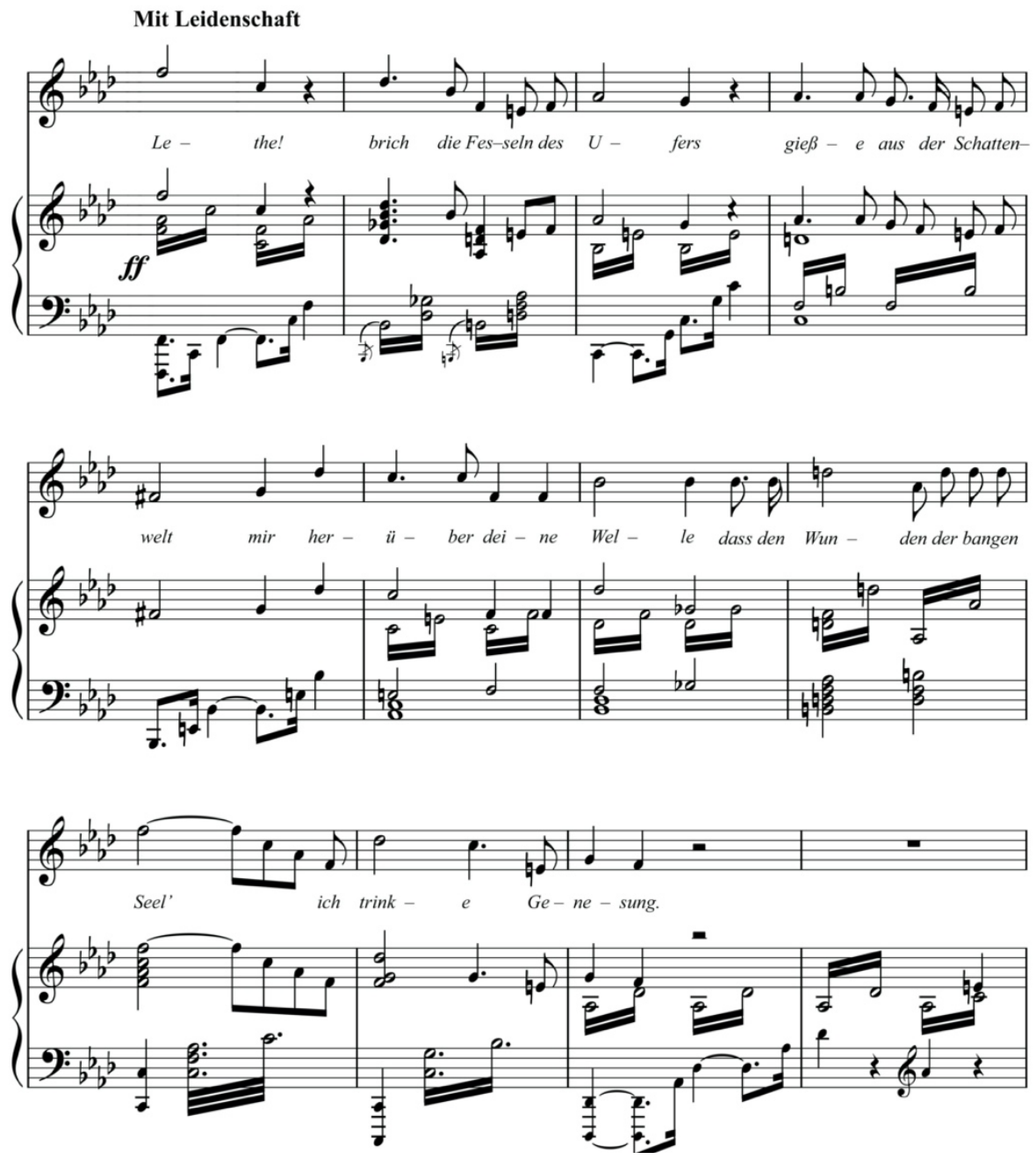
Exemplo 2: Nepomuceno, Sehnsucht nach Vergessen, c. 7-18

A contraparte melódica de tais desenvolvimentos na harmonia é a irregularidade, o abandono do "esquema periódico [...] do agrupamento em $2+2$, $4+4$ e $8+8$ compassos, que Wagner posteriormente, após ter ele rompido com ele, ridicularizou como quadratura da construção musical" (Dahlhaus 1996, p. 32) no espírito do que Wagner concebia como Versmelodie ("melodia de versos"), cuja ideia central seria fazer refletir na música as menores nuanças de inflexão e acentos da fala, e, novamente, da unendliche Melodie: "uma melodia é 'infinita' quando cada [...] momento musical é tanto dramaticamente relacionado, quanto internamente conectado com outros momentos" (Dahlhaus 1994, p. 106). No caso de Sehnsucht nach Vergessen, o poema de Lenau trazia ainda o elemento ideal para um text-setting wagnerista: as orações não coincidem com os versos, convidando assim à composição de frases musicais irregulares:

\author{
Sehnsucht nach Vergessen \\ Lethe! brich die Fesseln des Ufers, gieße \\ Aus der Schattenwelt mir herüber deine \\ Welle, dass den Wunden der bangen Seel ich \\ Trinke Genesung. \\ Frühling kommt mit Duft und Gesang und Liebe, \\ Will wie sonst mir sinken ans Herz; doch schlägt ihm \\ Nicht das Herz entgegen wie sonst. - O Lethe! \\ Sende die Welle! $!^{9}$
}

Como no Wagner do Ring, "a sintaxe regular [é] quebrada e dissolvida em 'prosa musical' [musikalische Prosa]: frases com extensão desigual e irregular são justapostas" (Dahlhaus 1996, p. 34) (Tabela 1). Do ponto de vista formal geral, contudo, Sehnsucht nach Vergessen aponta para uma recepção do Lied alemão até certo ponto em conformidade com os tradicionais limites estilísticos e formais do gênero: trata-se de uma forma $\mathrm{A}-\mathrm{B}-\mathrm{A}^{\prime}$, ancorada na tonalidade de fá menor nas

\footnotetext{
${ }^{9}$ Ânsia pelo esquecimento / Letes! Rompe as correntes da margem, verte / Do mundo das sombras sobre mim tua / Onda, que das chagas da alma atormentada eu / Bebo à saúde / Primavera chega com perfume e canto e amor, / Quer como de costume penetrar meu coração; mas para ela / Não bate o coração como antes. - Ó Letes! / Envia as ondas!
} 
MUSICA THEORICA Revista da Associação Brasileira de Teoria e Análise Musical 2020, v. 5, n. 1, p. 321-349 - Journal of the Brazilian Society for Music

seções externas e incluindo uma incursão à submediante diatônica (ré bemol maior) na seção central. Face a Einklang, poderíamos falar de uma aplicação relativamente mais difusa do estilo wagneriano.

\begin{tabular}{|c|c|c|c|c|c|c|}
\hline compassos & 1 & 7 & 17 & 35 & 45 & 48 \\
\hline seções & (introdução) & A & B & $\mathrm{A}^{\prime}$ & & $(\operatorname{cod} a)$ \\
\hline frases & $4+2$ & $3+4+3 \frac{1}{2}$ & $31 / 2+21 / 2+31 / 2$ & $3+4+2 \frac{1}{2}$ & 4 & 5 \\
\hline motivos & & $\mathrm{a}^{1}$ & $\mathrm{~b}$ & a & $a^{2}$ & \\
\hline harmonia & i (Fá menor) & $\mathrm{i}$ & VI & $\mathrm{i}$ & & $\mathrm{i}$ \\
\hline
\end{tabular}

Tabela 1: Nepomuceno, Sehnsucht nach Vergessen: visão geral de forma, extensão das frases, motivos e plano harmônico

\section{Interlúdio: o wagnerismo de Nepomuceno em Artémis}

Após suas primeiras tentativas no campo da canção wagnerista, representadas não apenas pelos Fünf Gedichte von Nicolaus Lenau für eine Singstimme, como também pelas duas canções em francês sobre poemas de Maurice Maeterlinck, Oraison e Désirs d'hiver, compostas igualmente no período de estudos na Schola Cantorum de Paris (ver Coelho de Souza 2005 e 2010), Nepomuceno continuou a dedicar-se à questão. Seu interesse pela estética wagneriana não apenas prolongou-se no Brasil, como também encontrou o microcosmo ideal para seu desenvolvimento nas duas instituições concebidas e então dirigidas, no Rio de Janeiro, pelo notório wagnerista Leopoldo Miguéz: além do Instituto Nacional de Música, o "Centro Artístico" multidisciplinar criado e presidido por Miguéz em 1893 "ao lado de Marques Neto, dos irmãos Bernardelli e de um grupo de intelectuais" (Corrêa 2005, p. 36). De fato, como não interpretar este último, com suas comissões "de música" (com Arthur Napoleão e Alfredo Bevilacqua, e integrada por Nepomuceno ainda quando ausente do país), "teatral" (com Aluísio de Azevedo), "de pintura" (Henrique Bernardelli, entre outros), "de escultura" (com Rodolfo Bernardelli), "de letras" (com Coelho Neto) e finalmente "de festas", com uma legítima projeção institucional da Gesamtkunstwerk wagneriana? ${ }^{10}$ Não por acaso, era Coelho Neto o libretista não apenas do primeiro ensaio wagneriano completo de Nepomuceno, Artémis (1898), como também das óperas de Leopoldo Miguéz Pelo

\footnotetext{
${ }^{10} \mathrm{O}$ crítico Oscar Guanabarino referia-se à organização, à época da estreia de Artémis, como “Centro Shakeswagneriano" (O Paiz 3 nov. 1898, p. 2).
} 
amor ("poema dramático" de 1896-97) e Os saldunes (traduzida posteriormente para o italiano como I salduni, 1898-1901).

Uma breve consideração de Artémis servirá aqui, portanto, como ilustração do aprofundamento da compreensão de Nepomuceno da linguagem musical wagneriana nos anos separando sua produção parisiense da canção em português Turqueza, com a qual parece culminar sua absorção e domínio desta que, com efeito, já foi descrita como uma "segunda prática" da tonalidade do século XIX. ${ }^{11}$ Em Artémis, "episódio lírico em um ato"12 estreado em 1898 no Teatro São Pedro no Rio de Janeiro, ${ }^{13}$ constatamos de fato os desdobramentos da recepção de Wagner, refletida e aplicada agora ao habitat natural da linguagem deste compositor: o gênero operístico. Como em Einklang, detecta-se aqui uma clara recepção de Tristan und Isolde, ${ }^{14}$ a qual pode ser apreciada a partir de uma consideração de seu prólogo instrumental, que oferece não apenas um exemplo de aufgehobene Tonalität, como também uma citação do "acorde de Tristão" transparecendo, agora, uma compreensão muito clara de um aspecto essencial do estilo wagneriano: a instrumentação. Analisemos, portanto, os dois aspectos.

Embora a partitura sugira a tonalidade de mi bemol maior, esta só é afirmada nos compassos finais da obra, passando ela já nos primeiros compassos, que estabelecem o modelo para a progressão modulatória que segue, à mi bemol menor. Os compassos finais do prólogo (c. 138-139 na partitura orquestral; na redução para piano em versão alemã ${ }^{15}$ encontra-se neste ponto a indicação "Der

${ }^{11}$ Por exemplo em Kinderman, William; Krebs, Harald (Eds). 1996. The Second Practice of Nineteenth-Century Tonality. Lincoln, London: University of Nebraska Press.

12 "Episódio trágico", no manuscrito da redução para canto e piano em versão alemã (tradução de Nepomuceno).

${ }^{13}$ A estreia pouco feliz é reportada por Vincenzo Cernicchiaro: "Artémis, com todas as suas qualidades que a distinguiam, foi sacrificada pelo elenco vocal, vencido pela timidez do momento, e pela inexperiência da arte cênica" (1926, p. 267, tradução de Giulio Draghi e João Vicente Vidal).

${ }^{14}$ A influência wagneriana foi apontada inicialmente por Luiz Guilherme Goldberg, que comparou um trecho do prólogo de Artémis e passagens de César Franck e Vincent d'Indy aos primeiros compassos do prelúdio de Tristan (2007, p. 99-100).

${ }^{15}$ Embora a primeira representação de Artémis no Rio de Janeiro tenho sido a da versão original em português, a partitura seria publicada a seguir em versão bilíngue português-francês (tradução de Iwan d'Hunac, pseudônimo de João Itiberê da Cunha, e Luís de Castro). Por tal 
Vorhang geht auf; Erster Auftritt", "Sobe a cortina; primeira entrada", delimitando o final da introdução orquestral) chegam ao acorde de sexta aumentada alemã (Lá - -Dó-Mi - -Fá\#), resolvido a seguir no acorde de dominante com nona $\left(V^{9}\right)$ de Dó maior no c. 140 (que conduz então a Dó maior, no comp. 141). A tonalidade, portanto, permanece indefinida por todo o trecho, altamente modulatório e construído fundamentalmente sobre sequências. Observa-se nos c. 1-30 de Artémis o procedimento tipicamente wagneriano de utilizar sequências associadas àquilo que Ernst Kurth descreveria como Verkürzung ("encurtamento") do material temático (1920, p. 311), um procedimento bem exemplificado no prelúdio de Tristan, e que confere à passagem um sentido redobrado de urgência. A transformação da sequência modulatória de técnica de desenvolvimento (historicamente relacionada à seção central da sonata clássica) em procedimento de exposição do material, como notou Dahlhaus (1980 p. 4648) uma das mais significativas contribuições de Liszt e Wagner, surge aqui plenamente absorvida por Nepomuceno. Neste ponto, portanto, linguagem harmônica e concepção formal não podem ser mais compreendidas separadamente.

Quanto ao "acorde de Tristão", este ocorre já no quinto compasso de Artémis, mas desta feita caracterizando-se como citação de Tristan und Isolde de uma forma diversa daquela de Einklang. Desconsiderando a tendência de se identificar esta formação particular genericamente com o acorde "semidiminuto" (formação que ocorre aliás em canções de Nepomuceno como Drömd lyka, O wag' es nicht, Herbst, Oraison, dos anos de Berlim e Paris), convém apreciar o contexto em que o acorde ocorre, e em que medida este se assemelha com o contexto original de Tristan. Em Einklang, um ponto de contato inequívoco é a resolução do "acorde de Tristão" no acorde de sétima dominante $\left(\mathrm{V}^{7}\right)$ de Lá menor; em Artémis, por sua vez, surge como elemento de ligação o momento da instrumentação. A justaposição dos compassos iniciais de Tristan e Artémis basta, para revelar a compreensão de Nepomuceno da orientação timbrística de Wagner: a combinação de dois oboés, dois clarinetes em Lá, corne inglês, dois fagotes e violoncelos do primeiro (Ex. 3) é apenas levemente adaptada pelo segundo, que substitui clarinetes em Lá por clarinete e clarinete baixo em $\mathrm{Si}$, e

razão, a redução para canto e piano traduzida para o alemão a que nos referimos constitui uma terceira versão da obra, prova de que o compositor dedicou-se por longo tempo a ela. 
faz violoncelos serem dobrados pelos contrabaixos (Ex. 4). Em outras palavras, Nepomuceno havia compreendido o que Dahlhaus diz, a propósito da interdependência de harmonia e instrumentação em Wagner, e do surgimento ipso facto de um dos mais importantes desenvolvimentos técnico-estéticos da época:

A harmonia é sempre apontada [...] como a novidade musical no estilo de Tristan [...] [mas] ela torna-se analisável, porém [...], apenas em relação à melodia, ao contraponto e à instrumentação. [...] a categoria central da música por volta de 1900, Klang ["som"], compreendida no sentido de que harmonia e instrumentação surgem inseparáveis, é-a despeito de Berliozuma descoberta wagneriana (Dahlhaus 1994, p. 139-140).

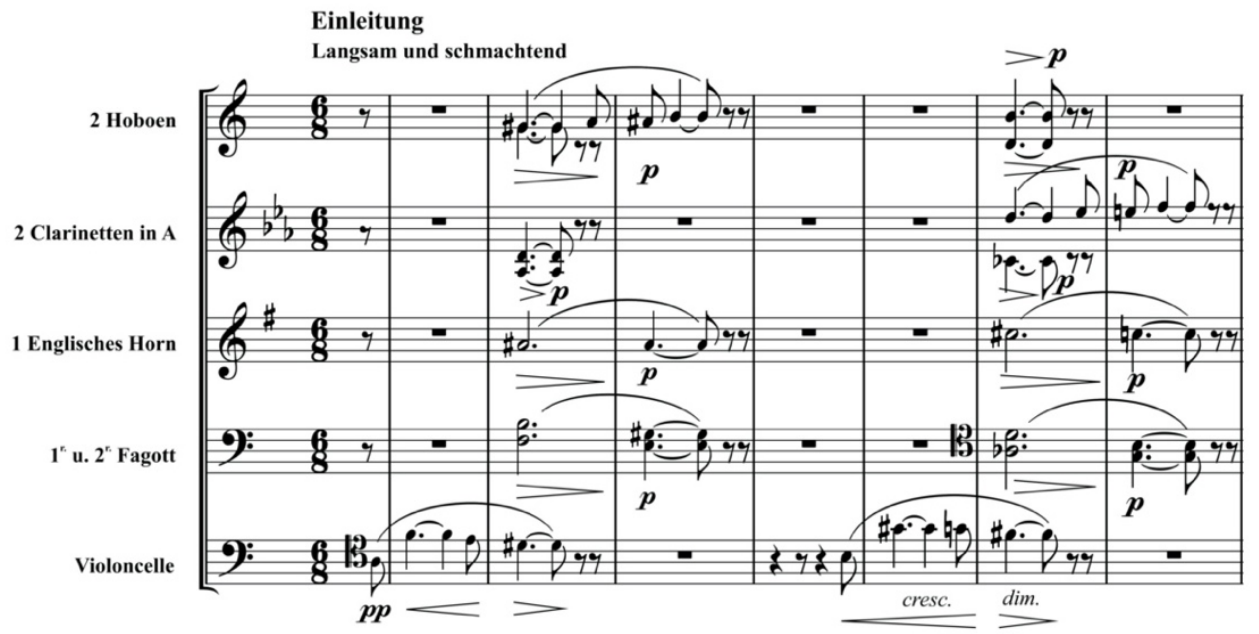

Exemplo 3: Wagner, Tristan und Isolde, c. 1-7

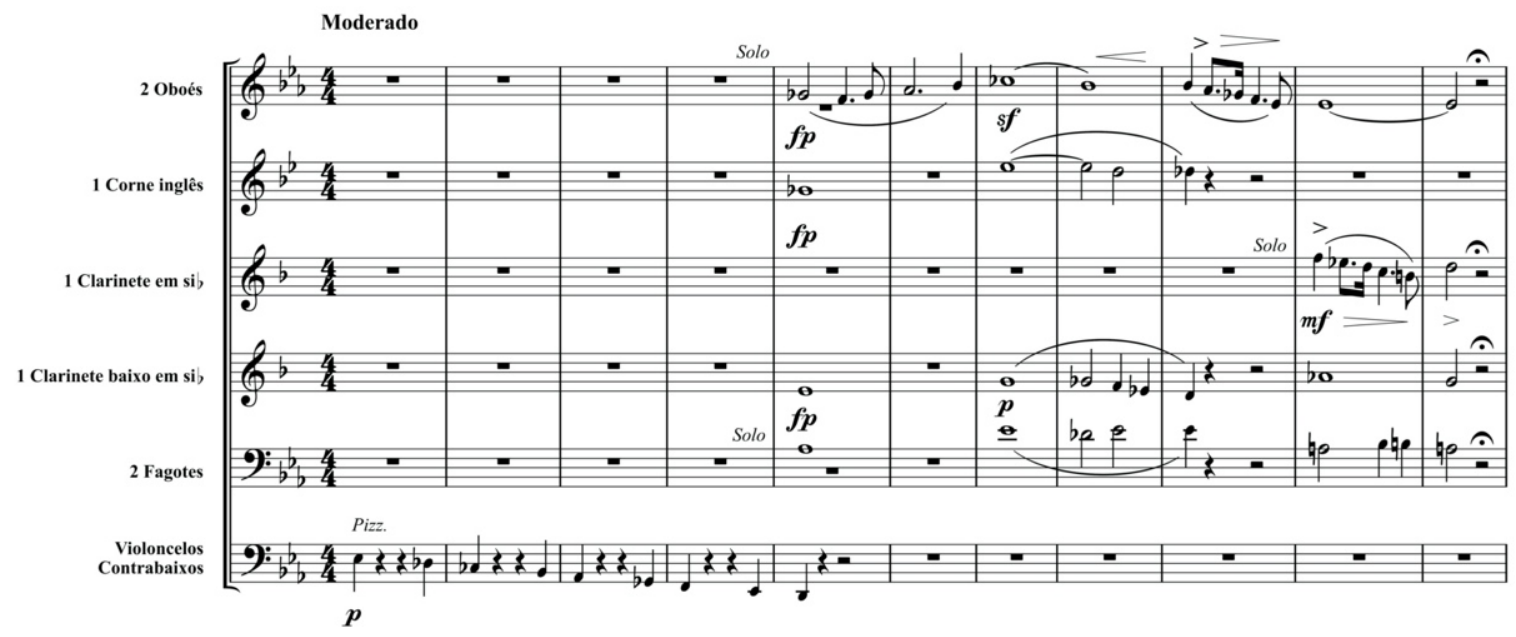

Exemplo 4: Nepomuceno, Artémis, c. 1-11, (“acorde de Tristão" no c. 5, ver Ex. 5) 


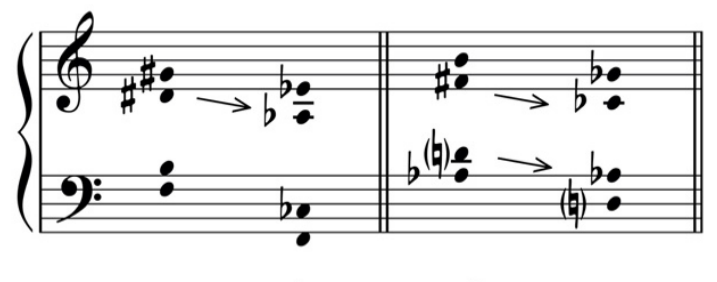

a $\quad$ b $\quad$ a' $\quad$ c

Exemplo 5: $\mathrm{O}$ "acorde de Tristão", em Wagner (a e a', prelúdio de Tristan und Isolde, c. 2 e 6) e em Nepomuceno (b, c. 17 de Einklang, c. 17; c, Artémis, c. 5). As setas indicam as inversões das alturas por Nepomuceno

Uma apreciação geral do wagnerismo de Nepomuceno dos anos 18941898, no que está exemplificado nas obras comentadas acima, revela uma compreensão de categorias musicais que se colocam para além do que Abbate chamou de "données clássicos" da análise de obras de Wagner: Leitmotiv ("motivo condutor"), forma e estrutura textual (1989, p. 42). Pode-se inferir como as principais razões para tal tenham sido o fato desta compreensão convencional do estilo wagneriano não ser prontamente adaptável ao gênero e meio do Lied, por um lado, e a escolha, como obra referencial, de Tristan und Isolde, frequentemente reconhecida como a mais "pura" partitura wagneriana (no que isso significa dizer a menos dependente do libreto, e mais "sinfônica", de suas obras). Tomar tal obra como reservoir de ideias e modelo teria implicado um estudo mais sistemático dos princípios composicionais ali contidos, decorrendo daí que uma compreensão aprofundada do sistema harmônico de Wagner, se não pode ser descrita como a única preocupação de Nepomuceno no período, pode ser apontada com segurança como a principal. E se é verdade que Nepomuceno logrou produzir em Artémis, mesmo tomando como referência uma obra da magnitude de Tristan und Isolde, uma obra não desprovida de marca pessoal, é sem dúvida um mérito nada insignificante para o compositor. Tal é, ao menos, a opinião e o testemunho do seu ilustre contemporâneo Vincenzo Cernicchiaro, a quem certamente não se poderia imputar qualquer simpatia por Wagner, e para quem

Artémis [...] sobre libreto, como dito, de Coelho Neto, [...] merece, malgrado tudo, ser incluído entre as boas obras do brilhante músico. A maioria considerou-a uma obra malograda. Mas quem sobre ela refletisse, quem sobre ela meditasse, encontraria na referida partitura (caso fosse executada por artistas ilustres) méritos não inferiores aos de Abul. Não é coisa fácil 
reunir, em um ato, tantas propriedades sonoras, concatenadas com facilidade e elegância, sem cair desastrosamente no plágio, e na monotonia. No direcionamento encontra-se, é verdade, a doutrina wagneriana, mas as belezas imitativas permanecem não privas de um certo valor pessoal (1926, p. 300).

\section{O wagnerismo de Nepomuceno e a canção vernacular: o caso de Turqueza op. 26 n. 1}

Como evidência da continuidade de seus esforços para o desenvolvimento de uma música vocal wagnerista em língua portuguesa, após a conclusão e estreia de Artémis, vemos Nepomuceno voltar-se mais uma vez ao problema de sua aplicação na canção de câmara em Turqueza, a primeira das Duas poesias op. 26 compostas em 1901 e estreadas em fevereiro de 1902 por Carlos de Carvalho, intérprete principal de Artémis em 1898, com o compositor ao piano. A proceder a informação de que Nepomuceno trabalhava em sua segunda ópera, Abul também marcada pela influência de Wagner, até mesmo na proposição do compositor de escrever não apenas a música, como também o libreto da ópera -, entre 1899 e 1905 (embora esta só viesse a ser estreada em 1913), é perfeitamente coerente que este mesmo traço revele-se em Turqueza, que podemos descrever aqui como uma terceira "solução" do compositor para o problema do Lied wagnerista (que parece refletir-se também em Hydrophana op. 26 n. 2).

Para as Duas poesias op. 26, tomou Nepomuceno a poesia do escritor, diplomata e cronista Luís Guimarães Filho (1878-1940), um parnasiano cujos dotes poéticos revelaram-se sobretudo em Versos íntimos (1894) e Pedras preciosas (1904). Com poesia de Guimarães Filho, Nepomuceno havia já composto a canção Madrigal op. 17 n. 2, em Paris (Corrêa 1996, p. 46), o que talvez explique a provável proximidade de ambos, evidenciada pela cronologia das publicações de Turqueza e Hydrophana, como música e como poemas. Com efeito, a publicação dos poemas deu-se apenas em 1904, quando surge em Montevidéu a primeira edição do livro "Pedras preciosas, versos originaes de Luis Guimarães (filho)"; o fato de Nepomuceno ter composto Turqueza e Hydrophana três anos antes, e ademais a inclusão de duas páginas de ambas as partituras no final desta primeira edição de Pedras preciosas (O Paiz 25 nov. 1904, p. 2), tornam inequívoco o contato entre compositor e poeta. Todos os elementos, portanto, confirmam a observação de 
MUSICA THEORICA Revista da Associação Brasileira de Teoria e Análise Musical 2020, v. 5, n. 1, p. 321-349 - Journal of the Brazilian Society for Music

Coelho de Souza sobre os poetas de língua portuguesa escolhidos por Nepomuceno para suas canções, entre os quais

encontramos [...] uma extensa lista de nomes pouco conhecidos. Quase todos são poetas seus contemporâneos, dos movimentos parnasianos e simbolistas [...]. Tudo leva a crer que Nepomuceno escolhia os poemas para suas músicas [...] pelo potencial de empatia que os textos lhe despertavam, vislumbrando a possibilidade de acrescentar uma dimensão que julgava faltar à obra enquanto literatura. A grande maioria dos textos que musicou era de poetas que deve ter conhecido pessoalmente (Coelho de Souza 2010, p. 42)

Atestando um especial interesse de Nepomuceno em Turqueza, encontramos anos depois (1906) uma orquestração do próprio compositor, com a especificação (ausente na versão original para canto e piano) "para voz media[,] barytono ou mezzo soprano". De fato, não é surpreendente que o compositor tenha vislumbrado a pertinência de uma orquestração da canção, considerando a complexidade do acompanhamento pianístico original, que se afasta do idiomatismo do instrumento para adquirir (embora de uma forma menos direta do que Sehnsucht nach Vergessen) um caráter de redução orquestral. Assim, Nepomuceno estabelece, já nos primeiros compassos da canção (cuja indicação de andamento - "Muito lento" - sem dúvida remete ao "Sehr langsam" de Tristan e de Einklang), uma intricada textura em três "camadas", o acompanhamento com indicação de compasso binário composto $\left(\begin{array}{l}6 \\ 8\end{array}\right)$, o canto de compasso binário simples $\left(\begin{array}{l}2 \\ 4\end{array}\right)$ :

1) Na parte superior do acompanhamento, com a indicação "a melodia bem distinta" (Ex. 6), temos porém uma organização rítmica que resulta de fato numa métrica ternária $\left(\zeta_{4}^{3} \cdot|\downarrow \cdot|\right.$ detc. $)$ - que será assumida na canção apenas na seção B (c. 23 e seguintes, Ex. 7), para depois, na transição para a recapitulação A' (c. 44-47), quando é finalmente submetida à mais extrema manipulação agógica de toda a peça (stringendo e crescendo/ritenuto, na longa linha cromática ascendente Dó-Ré,-Réł-Mi, -Mił-Fá-Sol,-Solł-Lá,-Láł-Si,-Dó-Réb-Ex. 8), caracterizar de forma mais inequívoca sua existência como espaço métrico em seu próprio direito (e não como hemíola localizada). A interação deste plano ternário com a linha binária do canto, uma polirritmia que perdura por toda a obra (notemos porém a inversão dos papéis na seção B, c. 30-35 e 40, o canto em compasso binário composto, a parte aguda do acompanhamento em binário simples), pode ser compreendida como a contraparte métrica da irregularidade da extensão das frases, ou seja, como reflexo, no plano da organização espacial, 
da quebra do "esquema periódico [...] [da] quadratura da construção musical" (Dahlhaus 1996, p. 32).
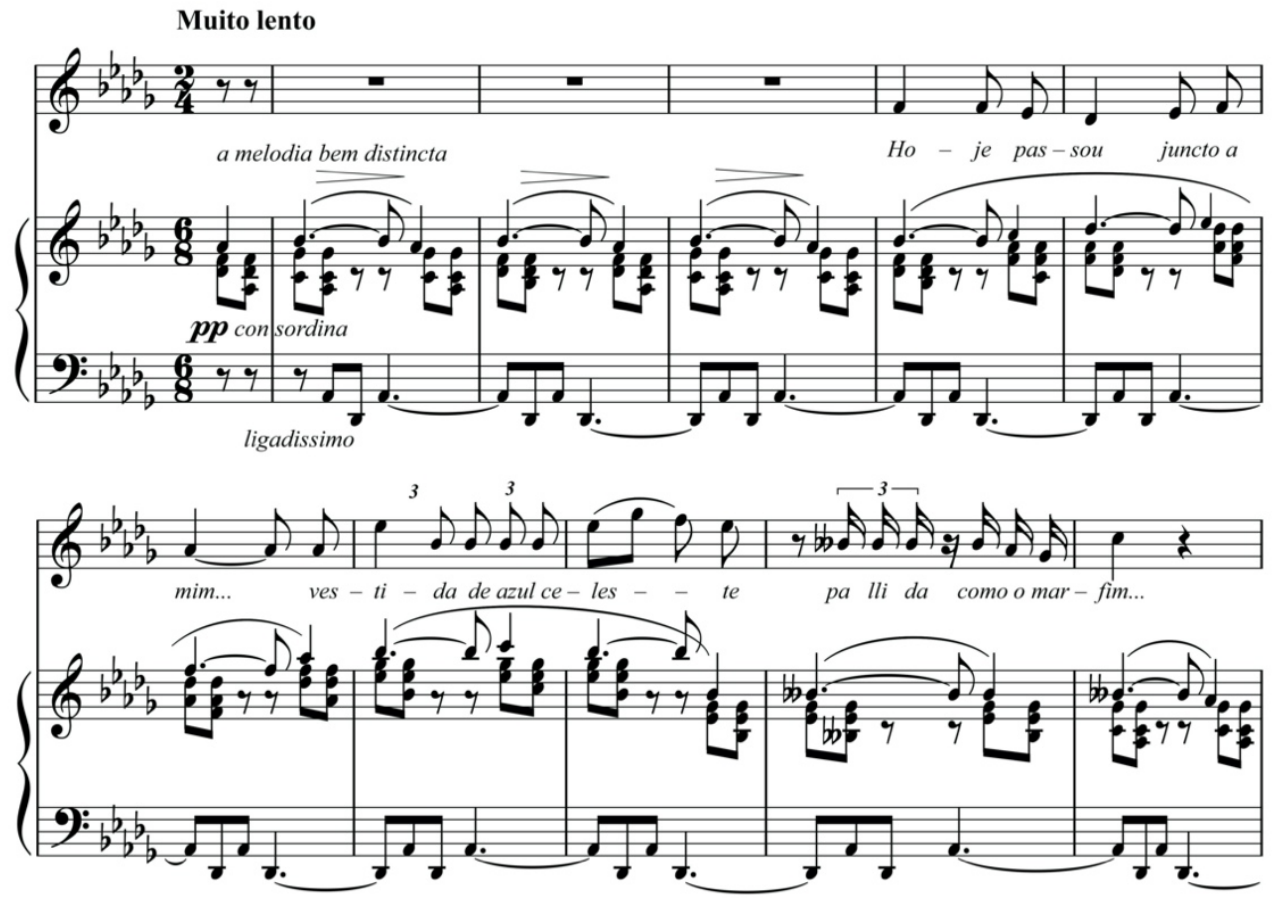

Exemplo 6: Nepomuceno, Turqueza, c. 1-10

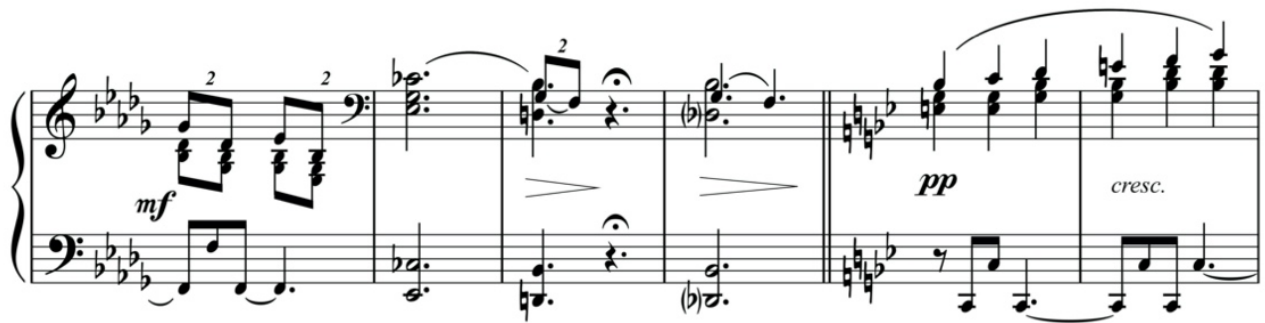

Exemplo 7: Nepomuceno, Turqueza, c. 19-24

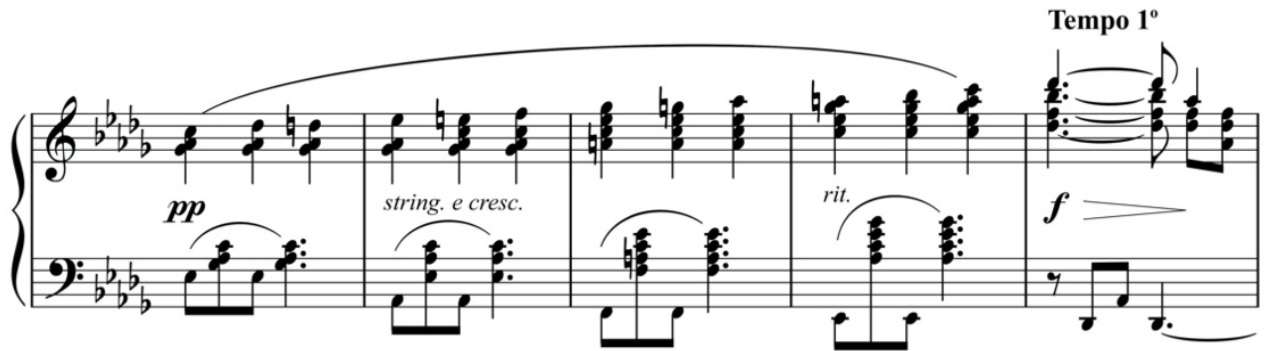

Exemplo 8: Nepomuceno, Turqueza, c. 44-48 
2) Na parte inferior do acompanhamento, vemos, pela maior parte das seções A e A', a constante reiteração da quinta Lá - -Réb (Ex. 6) em métrica binária

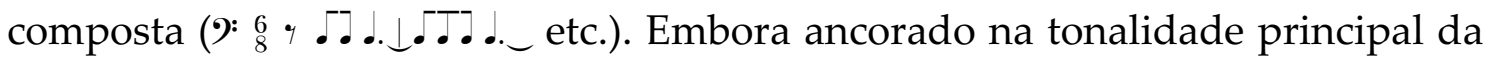
canção, este duplo pedal colabora para a criação de um ambiente (quase) "nãofuncional" cuja motivação parece encontrar-se na poesia de Guimarães Filho: se a fantasmagoria retratada ("Hoje passou juncto a mim... / Vestida de azul-celeste, I Pálida como o marfim...") convida à imobilidade, a sua interrupção, na segunda estrofe, dá-se apenas com a indicação de um movimento, mas agora não físico, e sim simbólico ("Dos seos olhos vi baixar / Uma sombra de cypreste!") - uma forma sutil de Wortmalerei. Neste ponto (c. 15), é permitido ao baixo descender cromaticamente, perfazendo o momento da primeira seção em que a ambiguidade tonal maior-menor que perpassa toda a canção é explorada ao máximo (a linha descendente Ré,-Dó-Si,$-L a ́$, seguindo-se Fá, dominante de Si, menor, e finalmente a conclusão da seção A na submediante cromática, Si, maior ${ }^{16}$-Ex. 7). O tratamento harmônico de toda a passagem inicial em que persiste o pedal Lá - -Réb (c. 1-14) sugere, portanto, a intenção de Nepomuceno de criar algo como um ambiente tonal coerente com a descrição de schwebende Tonalität de Schönberg: "percebe-se que a tonalidade [...], embora possa ser inferida de cada passagem, [...] é sempre expressa de forma circundante" (Schönberg 1922, p. 460).

3) Na parte do canto, finalmente, e assim no plano melódico principal, temos o movimento em métrica binária simples $\left(\xi \frac{2}{4} \cdot \Gamma \mid \cdot\right.$ • . . etc., Ex. 6) cuja simplicidade e regularidade são contrastados pelo traço principal da melodia wagneriana: a irregularidade da extensão das frases. Como em Sehnsucht nach Vergessen, a aplicabilidade do princípio estaria diretamente dependente do texto a ser musicado; neste caso, novamente, a poesia de Guimarães Filho significou uma escolha ideal: cinco tercetos de versos heptassílabos (a assim chamada "redondilha maior" da tradição luso-brasileira de versificação), somadas a um verso final isolado, ofereciam de fato a combinação ideal de estrutura sólida (em acordo com o apreço pela forma próprio do parnasianismo, mas ainda assim fugindo ao esquematismo do soneto - que em outros exemplos da canção de câmara de Nepomuceno estaria associado à forma A-A-B-A (Coelho de Souza

${ }^{16}$ A delimitação da seção $\mathrm{B}$ a partir da mudança de armadura no compasso 23 significaria desconsiderar o mais importante indicativo desta articulação estrutural: a fermata no segundo tempo do c. 21, logo após o acorde de si bemol maior em sua primeira inversão. 
2010, p. 41) e irregularidade, o que possibilitou tanto a estruturação de Turqueza em três grandes seção (A compreendendo os dois primeiros tercetos, B os dois seguintes, e $\mathrm{A}^{\prime}$ o terceto e verso isolado final), quanto a construção das frases irregulares do canto (Tabela 2), não raro incorporando o recurso (da Versmelodie wagneriana) de aproximar o canto do recitativo (por exemplo nos c. 9-10 e 14-15):

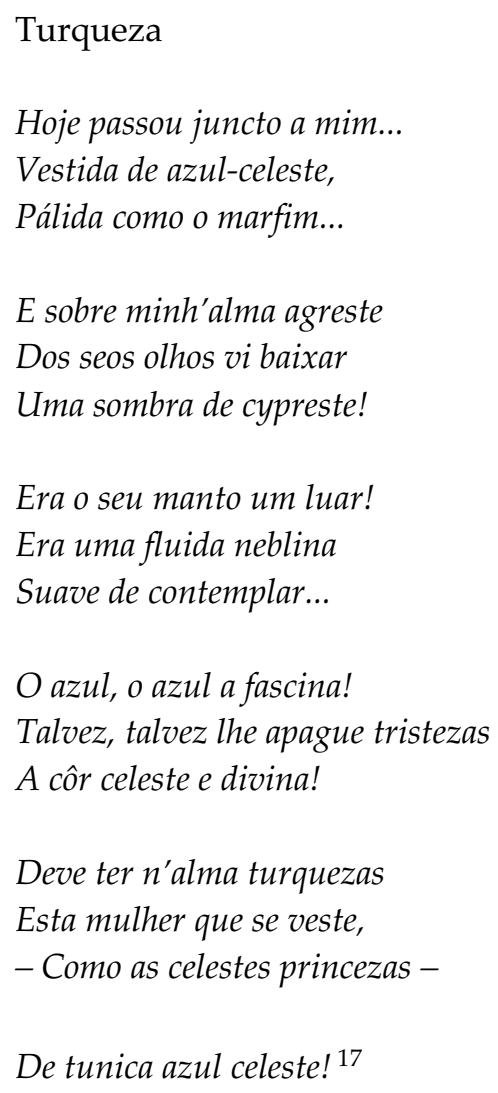

Como apreendemos desta descrição sumária dos elementos (ou "camadas") constitutivos de Turqueza, Nepomuceno logrou coordenar, nesta, recursos tipicamente wagnerianos anteriormente tratados de forma separada, em Einklang (concentrada nos parâmetros melodia e harmonia) e Sehnsucht nach Vergessen (concentrada nos parâmetros textura e frase), somando a estes, porém, um engenhoso uso do que David Kopp definiu como "tonalidade de tom comum", em que predominam relações de mediantes, sobretudo cromáticas

\footnotetext{
${ }^{17}$ Na versão final de Guimarães Filho, "Toda de azul celeste" no lugar de "Vestida de azul celeste"; a modificação é provavelmente de Nepomuceno, que converteu assim um verso heptassílabo em octassílabo.
} 
MUSICA THEORICA Revista da Associação Brasileira de Teoria e Análise Musical 2020,

v. 5, n. 1, p. 321-349 - Journal of the Brazilian Society for Music

(2002, p. 1-2), ${ }^{18}$ associada aqui, portanto, à "tonalidade flutuante" de Wagner (no que esta significa o orbitar de estruturas harmônicas em torno de um centro). Desta forma, Nepomuceno concilia um princípio relativamente (considerando, como sugeriu Abbate, que "por volta do final do século XIX, as modulações 'inaceitáveis' de Wagner [...] tinham se tornado a mais comum das moedas" (1989, p. 56) avançado de composição com o "aspecto aceito e bastante explorado da prática harmônica oitocentista" (Kopp 2002, p. 18) ${ }^{19}$ representado pelas relações cromáticas entre tríades e tonalidades.

A hipótese que se afigura aqui é que a construção de relações cromáticas coloca-se, para Nepomuceno, como recurso capaz de compensar a menor proeminência, na "instrumentação" específica do gênero do Lied, do elemento "timbre", ou seja, do Klang wagneriano. É especificamente na seção B, com suas duas subseções em $\mathrm{Si}$, maior e Lá maior, que observamos o contraste tonal obtido pela incursão através das duas submediantes cromáticas, incursão textualmente motivada ("Era o seu manto um luar! / Era uma fluida neblina", na primeira subseção; "O azul, o azul a fascina! / [...] A côr celeste e divina!", na segunda) e empreendida por transformações cromáticas resultando no encadeamento de acordes de quatro sons com amplo aproveitamento de alturas comuns e movimentos ("parcimoniosos") de $2^{\text {a }}$ maior e menor (Ex. 9). Ou seja, com o emprego de todos os elementos capazes, sob a ótica da "teoria neoriemanniana" - de forma alguma incompatível com a "complicação da técnica da dissonância" associada à "tendência à cromatização dos acordes, ao 'matizar' notas individuais através de elevação ou abaixamento" (Dahlhaus 1996, p. 106) de Wagner-, de dotar a música cromática do período da "coerência harmônica" perdida com o abandono de práticas tonais diatônicas.

\footnotetext{
${ }^{18}$ Kopp define "tonalidade de tom comum" como um "espaço harmônico cromático estável [...] contendo mais relações que o espaço diatônico mas menos que um [espaço harmônico] completamente saturado", apontando como seu aspecto definidor "o requerimento de um tom comum em cada relação cromática direta" e argumentando, ainda, que tais relações de tom comum "constituíram o primeiro grupo de relações cromáticas entre tríades e tonalidades a ser tornar completamente normalizado na prática harmônica oitocentista" (Kopp 2002, p. 1-2).

${ }^{19}$ Como esclarece Kopp, "na música de Beethoven e Schubert [...] [relações de mediante cromáticas] começaram a ocorrer com maior regularidade e a encontrar espaço em contextos harmônicos mais locais. À medida em que sua presença aumentou e seu perfil tornou-se mais familiar, as relações cromáticas de terças gradualmente tornaram-se um aspecto aceito e bastante explorado da prática harmônica oitocentista" (Kopp 2002, p. 18).
} 


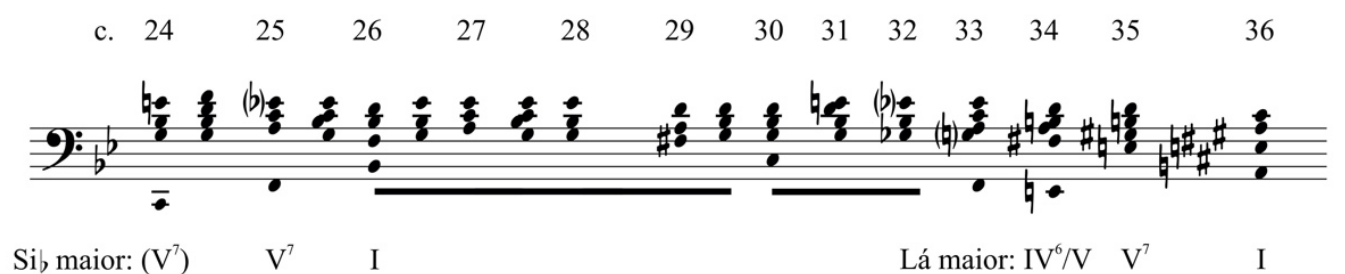

Exemplo 9: Nepomuceno, Turqueza, c. 28-36 (redução)

Neste contexto, figurações cromáticas melódicas como a linha descendente do baixo nos c. 15-23 (Réb-Dó-Si b-Lák [...] Mi,-Réł-Réb-Dó), ou ascendente da voz superior do acompanhamento pianístico nos c. 44-47 (DóRéb-Réı-Mib [...] Láł-Si,-Dó-Réb), colocam-se mais como uma expressão secundária do cromatismo da linguagem harmônica de Nepomuceno. Mais relevante, de fato, é a "emancipação da melodia" (Dahlhaus 1996, p. 33) que se observa nas subseções de B construídas sobre as submediantes cromáticas: se em $a$ a melodia inicia-se com movimentos de $2^{\text {a }}$ maior, temos em $b$ o delineamento da tríade de Sol menor (intervalos de $3^{\mathrm{a}}$ ), e em $c$ a projeção melódica do acorde de Lá maior com sexta (intervalos de $3^{\mathrm{a}}$ e $4^{\mathrm{a}}$ ) (note-se aqui, novamente, que a ambiguidade maior-menor de A persiste por toda a canção).

\begin{tabular}{|c|c|c|c|c|}
\hline compassos & 1 & 4 & 22 & \\
\hline seções & (introdução) & A & B & \\
\hline frases & 3 & $8(7+1)+10(7+3)$ & $14(4+3+4+2)+$ & $12(3+5+4)$ \\
\hline motivos & & $\mathrm{a}^{1}$ & $\mathrm{~b}$ & c \\
\hline harmonia & I (Réb maior) & I & VI & $\mathrm{VI} b$ \\
\hline
\end{tabular}

Tabela 2: Nepomuceno, Turqueza op. 26 n. 1: visão geral de forma, extensão das frases, motivos e plano harmônico

\section{Considerações finais}

Na historiografia musical brasileira, grande destaque foi dado ao papel de Nepomuceno no processo de formação de uma canção de câmara "brasileira"; pouca atenção se deu, porém, ao papel do wagnerismo do compositor neste mesmo processo. Prefaciando o volume de canções de Nepomuceno publicado em 2004 pela Editora da Universidade de São Paulo, Coelho de Souza acertadamente explica a histórica vinculação de Nepomuceno ao duplo debate do canto em português e do nacionalismo musical brasileiro como "subproduto" 
dos embates do compositor com o crítico Oscar Guanabarino quando de sua volta ao Brasil em 1895, ou seja, como resultado de uma leitura modernista dessas mesmas questões (Coelho de Souza 2004, p. 16-17). Confirmam assim a necessidade de uma permanente revisão do paradigma modernista não apenas análises de obras como Turqueza, mas também o que dizem as próprias fontes primárias de pesquisa. Neste sentido, é surpreendente constatar a vitalidade do debate em torno de Wagner à época, inclusive quanto à canção de câmara no vernáculo, como atesta a resposta de Nepomuceno a Guanabarino, quando acusado por este de "plágio" de Schubert, em sua canção Amo-te muito (Paris, 1894):

O caso de plágio que o Sr. Guanabarino encontrou em meu Amo-te muito é realmente exato, tendo-se enganado o caçador sagaz de tais interessantes coisas somente na escolha do modelo de que me servi e que foi um dos Romances sans paroles de Mendelssohn, em mi bemol, ou um acompanhamento no dueto de Lohengrin ou do Tristan e Isolda [sic], ou do Mage de Massenet [...] (A Notícia 2 nov. 1895, p. 3).

Avanços futuros na questão deverão considerar que, para compositores da geração de Nepomuceno, o wagnerismo significou não apenas um desafio estético e técnico, mas sobretudo uma operação de risco. Um aspecto claro do fenômeno, que colocava "imitadores" de Wagner em clara desvantagem, em comparação com compositores do final do século voltados a outros modelos (como Brahms, para citar um dos mais relevantes da época), é que as obras assim produzidas pareciam excessivamente problemáticas quando confrontadas com o "tipo ideal" estabelecido pelo drama musical wagneriano. Não por outra razão obras como Os saldunes de Leopoldo Miguéz receberiam juízos depreciativos como o de Rodrigues Barbosa, que considerando a reforma de Wagner era "de tal sorte completa que só admite imitadores", foi levado necessariamente a concluir Os saldunes seria uma obra prima, mas somente "se Wagner não houvera existido" (Barbosa 2007, p. 24).

Quanto ao desafio estético e técnico-para não dizer teórico-do wagnerismo, este era frequentemente dificultado por duas contingências adicionais: a necessidade ou desejo de transpor categorias wagnerianas para gêneros inteiramente diversos daquele em cujo escopo Wagner trabalhou, e a aglutinação desses mesmos elementos wagnerianos com outros, de origens diversas. Como incorporar ao gênero sinfônico uma concepção construtiva não 
mais "arquitetônica", como em Beethoven, mas baseada agora em uma "rede" motívica desprovida de qualquer teleologia puramente musical? Para Bruckner, explorando o aspecto sonoro da linguagem wagneriana (o momento da instrumentação, portanto) nos limites da concepção formal tradicional do gênero. Da mesma forma, como transpor para um gênero essencialmente camerístico e de pequena escala como o Lied conceitos concebidos para formas contínuas e de amplo alcance? Para Wolf, explorando aspectos da harmonia estendida e da melodia emancipada de Wagner nos limites de um gênero de extensão mínima, em que a unidade composicional se torna indissociável do que, em outros gêneros, não seria considerado senão como um evento de nível "local". Os exemplos seriam inúmeros, em praticamente todos os gêneros, estilos e formações, do final do século XIX até as primeiras décadas do XX. Mais importante do que enumerá-los, contudo, é notar que a aplicação da linguagem wagneriana, atrelada em sua origem à palavra e à ação cênica, a gêneros eminentemente não-wagnerianos envolveu sempre um grau de compromisso de ambas as partes (por exemplo o abandono do conceito de Leitmotiv, supérfluo em um gênero como o Lied), compromisso que se coloca assim como um dos principais objetos da análise desse repertório.

Para além de tais considerações, resta novamente claro o caráter nãoproblemático, para Nepomuceno, do "compor segundo modelos" (como dito em A Notícia: "o modelo de que me servi..."). De fato, seu "epigonismo" será sempre mais bem compreendido se tomado, como sugeriu Markus Fauser (1999), como uma poética em seu próprio direito, onde a intertextualidade se revela como crítica da tradição e da própria subjetividade, e não simplisticamente como atividade criativa emulatória. Em outras palavras, se compreendido como fenômeno indissociável do historicismo do século XIX, tão distante da imitatio setecentista quanto de uma estética centrada na categoria do gênio absolutamente original. Para Nepomuceno, e aí está sem dúvida uma lição aprendida de Brahms, compor a partir de obras exemplares do repertório (Tristan und Isolde, na maior parte dos exemplos aqui enfocados) significava acima de tudo fundamentar sua música nas melhores ideias do passado, fazendo assim elaboratio suplantar inventio. Valia para ele o "efeito obtido", o "resultado estupendo", mais do que considerações sobre originalidade tidas hoje, como não menos também em seu tempo, como largamente irrelevantes para a valoração da obra artística. 
Como visto, Nepomuceno dedicou-se intensamente ao "problema Wagner" não apenas durante seus anos de formação na Europa, mas também depois, por longo período, no Brasil. No âmbito da canção de câmara, a sua recepção composicional de Wagner atravessou algumas etapas diversas, que buscamos retratar minimamente nesta contribuição: em um polo, as canções em alemão do ciclo Fünf Gedichte von Nicolaus Lenau onde encontramos delineadas o que chamamos de duas "soluções" para o problema do Lied wagnerista; em outro, a canção em português Turqueza op. 26 n. 1, em que detectamos, como terceira "solução" para o problema, o acúmulo de todos procedimentos anteriormente absorvidos, que surgem agora na obra com complexidade redobrada. Como procuramos enfatizar, um papel decisivo neste aprofundamento da compreensão de Nepomuceno de "categorias" wagnerianas de composição musical foi desempenhado por um lado pelo estudo de Tristan und Isolde, e por outro pela composição da ópera Artémis, que ocupa um lugar central na produção do compositor, no período analisado.

Nada disso contradiz o fato de também encontrarmos na obra de Nepomuceno muitos outros traços, de compositores tão diversos quanto Brahms, Grieg, Duparc e Debussy: uma característica do "ecletismo" nas artes-percebido não como uma fraqueza estética, no fin-de-siècle, mas ao contrário como atestado de cosmopolitismo-é a noção de que determinados estilos pertencem a determinados gêneros, isto é, de que o estilo está em função do gênero, e não o contrário. Para Nepomuceno, como para tantos outros compositores brasileiros da mesma época, diferentes gêneros demandariam também estilos diversos e até mesmo contraditórios, sendo o ofício do compositor saber "encená-los" a cada oportunidade. Cabe à pesquisa musical brasileira, portanto, mapear e aprofundar a compreensão dos passos de seus mais importantes compositores no contexto maior do complexo processo de transferência cultural aí implicado, do qual o wagnerismo de Nepomuceno é apenas uma pequena-e todavia eloquenteamostra.

\section{Referências}

1. Abbate, Carolyn. 1989. Wagner, "On Modulation", and Tristan. Cambridge Opera Journal, v. 1, n. 1, p. 33-58.

2. Barbosa, José Rodrigues. 2007. Um século de música brasileira; reedição do texto publicado em O Estado de S. Paulo, 9-19 set. 1922; pesquisa, 
estabelecimento do texto, introdução e notas de Paulo Castagna. São Paulo: Relatório de Pesquisa Trienal para o Instituto de Artes da UNESP.

3. Campos, Rémy; Donin, Nicolas. 2009. Wagnérisme et analyse musicale. L'émergence de nouvelles pratiques savantes de lecture et d'écoute en France à la fin du XIXe siècle. In: Campos, Rémy; Donin, Nicolas (Eds). L'Analyse musicale, une pratique et son histoire. Genève: Droz, Conservatoire de GenèveHEM, p. 35-80.

4. Cernicchiaro, Vincenzo. 1926. Storia della musica nel Brasile. Dai tempi coloniali sino ai nostri giorni (1549-1925). Milano: Fratelli Riccioni.

5. Coelho de Souza, Rodolfo Nogueira. 2012. A influência do simbolismo nas óperas de Alberto Nepomuceno. In: Volpe, Maria Alice (Org.). Atualidade da ópera (Série Simpósio Internacional de Musicologia da UFRJ, v. 1). Rio de Janeiro: Escola de Música, p. 223-231.

6. . 2010. Nepomuceno e a gênese da canção de câmara brasileira (1 ${ }^{a}$ parte). Música em Perspectiva, v. 3, n. 1, p. 33-53.

7. 2006. Aspectos de modernidade na música de Nepomuceno relacionados ao projeto de tradução do Harmonielehre de Schoenberg. Em Pauta, v. 17, n. 29, p. 63-81.

8. . 2005. Um estudo das canções de Alberto Nepomuceno sobre os poemas de Maurice Maeterlinck. In: Chueke, Zélia (Ed.). Brasil Musical. 1. ed. Curitiba: Universidade Federal do Paraná, v. 1, p. 67-78.

9. 2005. Prefácio. In: Pignatari, Dante (Ed.). Alberto Nepomuceno. Canções para voz e piano São Paulo: Edusp, p. 15-18.

10. Cook, Nicholas. 1987. A Guide to Musical Analysis. New York: Norton.

11. Corrêa, Sérgio Nepomuceno Alvim. 2005. Leopoldo Miguéz, catálogo de obras. Rio de Janeiro: Academia Brasileira de Música.

12. Corrêa, Sérgio Nepomuceno Alvim. 1996. Alberto Nepomuceno: Catálogo geral. Rio de Janeiro: Funarte.

13. Dahlhaus, Carl. 1980. Between Romanticism and Modernism. Four Studies in the Music of the Later Nineteenth Century. Berkeley, Los Angeles: University of California Press.

14. . 1996. Richard Wagners Musikdramen. Ditzingen: Reclam.

15. Dahlhaus, Carl; Deathridge, John. 1994. Wagner. Stuttgart, Weimar: Verlag J. B. Metzler. 
MUSICA THEORICA Revista da Associação Brasileira de Teoria e Análise Musical 2020, v. 5, n. 1, p. 321-349 - Journal of the Brazilian Society for Music

16. Dudeque, Norton. 2005. Aspectos do academicismo germânico no primeiro movimento do Quarteto n. 3 de Alberto Nepomuceno. Ictus, v. 6, p. 211-232.

17. Fauser, Markus. 1999. Intertextualität als Poetik des Epigonalen. München: Wilhelm Fink.

18. Goldberg, Luiz Guilherme. 2007. Um Garatuja entre Wotan e o Fauno: Alberto Nepomuceno e o modernismo musical no Brasil. Tese (Doutorado em Música). Universidade Federal do Rio Grande do Sul, Porto Alegre.

19. Kopp, David. 2002. Chromatic Transformations in Nineteenth-Century Music. Cambridge: Cambridge University Press.

20. Kurth, Ernst. 1920. Romantische Harmonik und ihre Krise in Wagners "Tristan". Berlin: Hesse.

21. Mila, Massimo. 1957. Italien. In: Die Musik in Geschichte und Gegenwart, v. 6. Kassel: Bärenreiter, p. 1464-1574.

22. Nepomuceno, Alberto. 1890. Carta a Frederico Nascimento (Fundação Biblioteca Nacional, Divisão de Música e Arquivo Sonoro, Correspondência ativa de Alberto Nepomuceno).

23. Schäfer, Thomas. 1999. Modellfall Mahler: Kompositorische Rezeption in zeitgenössischer Musik. Munique: W. Fink Verlag.

24. Schönberg, Arnold. 1922. Harmonielehre. 3. ed. ampliada e melhorada. Wien: Universal Edition.

25. Vidal, João Vicente. 2020. Notas introdutórias ao Quarteto de cordas n. ${ }^{\circ}$ 3, 1. $^{\circ}$ mov. (primeira versão), de Alberto Nepomuceno. Revista Brasileira de Música, v. 33, n. 1, p. 489-500.

26. . 2015. Alberto Nepomuceno e o germanismo no Brasil. In: Vidal, João Vicente; Montez, Luiz Barros (Org.). Rio de Janeiro-Alemanha: relações musicais. Rio de Janeiro: Escola de Música, p. 16-36.

27. 2014. Formação germânica de Alberto Nepomuceno: estudos sobre recepção e intertextualidade. Rio de Janeiro: Escola de Música.

28. Zamith, R. M. (Org.). 2000. Alberto Nepomuceno. 15 manuscritos para canto. Rio de Janeiro: Escola de Música Villa-Lobos. 